\title{
A popularização da periguete em telenovelas brasileiras recentes ${ }^{1}$
}

Ligia Lana²

1 A primeira versão deste texto foi apresentada no seminário A visibilidade dos anônimos, promovido pelo Grupo de Pesquisa Mídia e Narrativa, da Pontifícia Universidade Católica de Minas Gerais (PUC-MG), em Belo Horizonte, nos dias 06 e 07 de novembro de 2013. 


\section{Resumo}

Este artigo apresenta reflexões sobre a popularização recente da figura da periguete no Brasil. O trabalho analisa duas personagens de telenovelas da Rede Globo: Natalie Lamour (Débora Secco), de Insensato coração, e Suelen (Ísis Valverde), de Avenida Brasil, através de três eixos: hábitos sexuais, relacionamentos amorosos e desfecho da narrativa. O objetivo é compreender as estratégias empreendidas por elas para a conquista da vida bem-sucedida, buscando desvendar alguns elementos culturais que tornam possíveis suas ascensões midiáticas. A conclusão indica que a periguete instala uma problemática de classe na mídia, perturbando a ordem invisível das desigualdades brasileiras.

\section{Palavras-chave}

Periguete, telenovela, sexo, mulher, mídia massiva.

\section{Abstract}

This paper analyses the recent popularization of ho in two Brazilian soap opera characters: Natalie Lamour (Deborah Secco) of Irrational Heart, and Suelen (Ísis Valverde) of Brazil Avenue, through three axis: sexual habits, love relationships and ending of the plot. The purpose is to understand the strategies undertaken by them for achieving a successful life; seeking to discuss the cultural elements that enable their rise in the media. Our conclusion indicates that the ho sets a class issue on the media, disrupting the invisible order of Brazilian inequality.

\section{Keywords}

Periguete, soap operas, sex, woman, mass media. 
A curiosidade que motiva este texto está relacionada à recente popularização da palavra periguete no Brasil. Apesar de ainda não figurar em dicionários como Houaiss ou Michaelis, o termo tornou-se conhecido e muito falado pelas pessoas na vida cotidiana. Periguete designa a mulher sensual, que usa roupas curtas, apertadas e decotadas, acessórios exagerados e salto alto, sobressaindo-se visualmente na paisagem social pela exposição do corpo, geralmente caracterizado por bronzeamento, cirurgias plásticas e próteses de silicone. O projeto de vida da periguete é alcançar a estabilidade financeira, empregando deliberadamente estratégias de sedução, sem demonstrar pudor ao exibir o corpo. A periguete frequenta ambientes, festas e baladas onde seja possível encontrar homens bem-sucedidos.

A sensualidade da periguete é traiçoeira e deve ser temida pelos homens. O risco explica o sentido da palavra: a periguete representa perigo - por isso, a grafia do termo com a letra " $\mathrm{e}$ "3. O perigo ameaçaria tanto os homens como a integridade física da periguete. Ao usar roupas provocantes e insinuar-se sexualmente, a periguete não se protegeria de possíveis assédios ou estupros. De acordo com este ponto de vista, a mulher é culpada em caso de violência sexual, pois o risco poderia ser evitado através de postura e roupas corretas ${ }^{4}$.

A palavra periguete tem sentido pejorativo. Assim como as antigas mulheres levianas, maçanetas, vagabundas e vadias, a periguete é malvista por sua sexualidade liberada. A periguete, por ser perigosa, assemelha-se à figura arquetípica da vagina dentata (em português, "vagina com dentes"). Em narrativas mitológicas, a vagina dentata ensina aos homens que o sexo, quando

Em trabalho anterior, havia usado a letra "i" na grafia da palavra (LANA et al., 2012). A continuidade da investigação me leva, neste momento, a adotar a letra "e". Agradeço pelas contribuições e críticas de João Freire Filho, supervisor de meu projeto de pesquisa, e pelo diálogo com Tatiane Costa, mestranda da Escola de Comunicação da UFRJ. uma declaração de um policial a respeito do aumento de casos de abuso sexual na Universidade de Toronto. Para ele, os incidentes seriam menos numerosos se as estudantes não usassem roupas de vadias ("slut"). O SlutWalk consiste em convocar mulheres, pela internet, para um encontro em que usem roupas justas e decotadas, proclamando a liberdade de se vestir sem que se tornem, por isso, penalizadas por abusos sexuais. Curiosamente, o estilo de roupas das periguetes e das manifestantes da Marcha das Vadias, nome do movimento no Brasil, é muito parecido. (BERALDO, 2012). 
praticado fora das regras sociais, pode levar à castração. O ambicioso projeto de vida da periguete pode arruinar o patrimônio financeiro dos homens; planejando golpes, a periguete demonstra que precisa ter clareza sobre seu futuro.

Em Thinking sex, Gayle Rubin (2011) mostra que a sexualidade humana é objeto de estudo fundamental em momentos de crise e convulsão social, quando temas como a pobreza, a guerra e o racismo parecem mais nobres para refletir sobre a organização da cultura. O sexo é instituição política e produz modos de opressão que se vinculam a outras estruturas de poder. Hoje em dia, diante da crescente erotização da cultura, a compreensão da popularização da periguete pode revelar articulações entre os valores ligados à sexualidade feminina e o sonho da ascensão social, em uma sociedade cada vez mais competitiva, constantemente atravessada por crises financeiras e pela exasperação de desigualdades econômicas.

De acordo com Rubin, a "produção de gênero" (papéis sociais construídos a partir das categorias homem e mulher) deve ser analisada de maneira distinta da "produção de sexo" (comportamentos sexuais caracterizados como positivos ou ofensivos), já que as desigualdades advindas de cada uma são diferentes. Ainda que sejam combinadas e complementares, como no caso das lésbicas, as estratificações de gênero e sexo não operam pelos mesmos mecanismos. Gayle Rubin analisa que, na constituição da sexualidade moderna, na Inglaterra e na Europa, no século XIX, a moralidade vitoriana apregoou a valorização castidade e o combate a vícios sexuais, ensinando normas sadias para o sexo.

O termo sex offender, por exemplo, ilustra o modo como a experiência da sexualidade foi construída: a partir de meados da década de 1930, assunto de medo e escrutínio público, "ofensor do sexo" se tornou um código para identificar, indistintamente, estupradores, pedófilos, homossexuais ou qualquer outro indivíduo considerado desviante. A categoria não diferenciava práticas violentas e ilegais de atos consensuais, o que contribuiu para uma suposta "epidemia de psicopatias sexuais", elevando o estigma de gays, prostitutas e travestis. 
Assim, uma "pirâmide erótica" posiciona, em seu topo, casais heterossexuais que mantêm relações sexuais com fins reprodutivos e, no extremo oposto, travestis, trabalhadores do sexo, atores pornôs e sadomasoquistas, indicando a valoração positiva, normal e natural de um tipo de sexo em oposição às práticas sexuais negativas, anormais e doentias.

Indivíduos cujos comportamentos se situam no topo desta hierarquia são recompensados com um certificado de sanidade mental, respeitabilidade, legalidade, mobilidades social e física, suporte institucional e benefícios materiais. Na medida em que comportamentos sexuais ou ocupações decrescem na escala, os indivíduos tornam-se submetidos a presumidas doenças mentais, má reputação, criminalidade, restrições às mobilidades física e social, perda de suporte institucional, sanções econômicas e acusações criminais (RUBIN, 2011, p. 177, tradução nossa) ${ }^{5}$.

A periguete se situa nas posições mais baixas da pirâmide erótica. Ainda que não seja comercial, a performance de sexo da periguete aproxima-se do comportamento de trabalhadores do sexo: realizando cálculos, ela oferece o corpo a determinados homens que possam recompensá-la, em troca, com a obtenção de seu projeto de vida.

A periguete retratada pela mídia traz contradições para a crítica da opressão erótica - e, consequentemente, das desigualdades de gênero. $\mathrm{Na}$ análise da presença das prostitutas nas cidades, Gayle Rubin demonstra que as injustiças sexuais empurram-nas aos guetos, às situações de violência e ao tráfico sexual. As periguetes, ao contrário, estão na televisão aberta, nas notícias mais lidas da internet e nos jornais populares, não ocupando um espaço totalmente marginalizado. Além disso, anônimas, elas se tornam, ainda que por pouco tempo, celebridades; são exemplos de periguetes a ex-dançarina do cantor Latino e vice-ganhadora do troféu Miss Bumbum, Andressa Urach; as "panicats" Mulher Samambaia, Carol Narizinho, Dani Bolina, Nicole Bahls; Maria Melilo e 
várias participantes do Big Brother Brasil; inúmeras outras mulheres célebres: Geisy Arruda, Joana Machado, Viviane Araújo, Carol Nakamura. Elaborando uma performance sexualmente desinibida, elas suscitam a adesão da sociedade, que, cada vez mais midiatizada, não esconde as periguetes, mas as posiciona em espaços sociais visíveis.

A periguete é fenômeno midiático recente, mas a visibilidade da mulher sensual surge com as primeiras formas de entretenimento, no cinema hollywoodiano. Nos anos 1940, o gênero noir produziu filmes policiais, em que as personagens femininas potencializam o mistério das tramas. A femme fatale e as subcategorias vamp, diva e good bad-girl possuem importância central no filme noir por sua sexualidade intensa e decisiva para a execução dos crimes, dando visibilidade ao corpo feminino que coloca a vida das pessoas em risco. A popularização da mulher fatal no cinema, como indicam Helen Hanson e Catherine O'Rawe (2010), remete ao final do século XIX, quando representações arquetípicas da sensualidade perigosa - personificadas por Eva, Dalila, Medusa e Salomé - foram reformuladas e se tornaram recorrentes nas artes visuais e na literatura. A mulher fatal moderna traz uma ruptura com a narrativa heroica tradicional, pois ela não deseja ser resgatada pelo homem; sendo uma agente importante da narrativa, a femme fatale transforma a passividade de papéis femininos na jornada do herói ${ }^{6}$.

Em minha pesquisa, tenho observado que as condutas da mulher sensual são cada vez mais marcadas por sentimentos de desembaraço, extroversão e naturalidade para usar a sensualidade em busca de espaço na mídia7. Ao contrário

De acordo com Ana Carolina Escosteguy (2013), a maneira como mulheres de classes populares narram suas histórias de vida toma como referência a jornada do herói. Elas "falaram, fundamentalmente, na primeira pessoa do singular. As narradoras posicionaram-se sempre no centro de suas histórias. E, mesmo os revezes - maternidade precoce, doenças, separação, divórcio, excesso de mudanças de cidades em função dos companheiros ou a morte de um familiar - foram transformados afirmativamente em rupturas motivadoras para que seguissem adiante. (...) A superação dos revezes dá-se através de valores como a abnegação, o sacrifício e a dedicação, vivenciados no cotidiano, encarnados no trabalho, e a partir dos quais as entrevistadas parecem sentir-se valorizadas. São esses traços de caráter que encontramos nas narrativas coletadas os quais permitem às mulheres erigirem-se em heroínas" (ESCOSTEGUY, 2013, p. 150-151). 
da femme fatale do cinema, as celebridades não são misteriosas, afirmando claramente seu projeto de vida - ter fama, dinheiro e reconhecimento. A celebrização de mulheres como Catarina Migliorini, que leiloou sua virgindade na internet, implica o uso explícito da sensualidade na busca por visibilidade (LANA, 2013). Nesse sentido, a periguete articula uma performance de sexo complexa: possui prática sexual considerada negativa, mas ocupa espaço privilegiado no visível midiático; apresenta-se como mulher sedutora, no entanto, contraria a ambiguidade da femme fatale.

Este artigo apresenta algumas reflexões sobre a popularização da periguete através da análise de duas personagens de recentes telenovelas da Rede Globo: Natalie Lamour (Débora Secco), de Insensato coração, e Suelen (Ísis Valverde), de Avenida Brasil. Nos dois casos, trata-se de mulheres comuns em busca de ascensão social através do corpo sensual. Natalie e Suelen também se envolvem em situações midiáticas, alcançando, em diferentes proporções, o estatuto de celebridade. Além disso, as personagens não pertenciam ao núcleo principal da trama, mas alcançaram muito sucesso junto ao público: passaram a ocupar mais espaço no enredo na telenovela e tiveram suas músicas-tema muito tocadas ("Ela é a minha cara", de Martinália, e "Correndo atrás de mim", de Aviões do Forró).

A presença significativa de periguetes nos enredos de telenovelas recentes sugere que pode estar havendo transformações nas representações femininas da mídia ${ }^{8}$. Segundo Heloísa Buarque de Almeida (2007), as heroínas das telenovelas da Rede Globo, de maneira hegemônica, incorporam valores das classes médias, trazendo anseios feministas em suas relações afetivas, hábitos sexuais e vidas cotidianas: "Mas para não se tornarem incômodas ou ousadas demais aos setores mais conservadores da população $(\ldots)$, que também constituem parte do mercado consumidor buscado, mantêm também coerência com valores ditos tradicionais como ser boa mãe e dedicar-se à família" (ALMEIDA, 2007, p.183). 
A periguete não é uma heroína, mas, tornando-se popular, instaura rupturas nesse quadro. Em primeiro lugar, ela não pertence às classes médias, o que significa, no Brasil, não ser contemplada pelas conquistas feministas. O sexo, por exemplo, não é requisito para a construção da cumplicidade no relacionamento afetivo e pode ser usado, naturalmente, para manipular os homens, confirmando a análise de Patrícia Mattos (2006). Em segundo lugar, a periguete não encarna valores tradicionalmente associados aos papéis femininos, como ser boa mãe. A temática da maternidade, quando enfocada, surge normalmente relacionada ao "golpe da barriga". Tendo em vista esses aspectos, as reflexões deste artigo buscam compreender as personagens Natalie Lamour e Suelen a partir de três eixos analíticos: hábitos sexuais, relacionamentos amorosos e desfecho da narrativa9.

\section{A personagem Natalie Lamour}

Em Insensato coração, de autoria de Gilberto Braga e Ricardo Linhares, exibida entre 17 de janeiro e 19 de agosto de 2011, em 185 capítulos, a personagem Natalie Lamour foi uma finalista do reality show "Volúpia na montanha"10. Famosa na mídia, ela havia trabalhado como celebridade por algum tempo não apenas durante a bem-sucedida participação no reality, mas na publicidade e nos ensaios de fotografia erótica. Com o dinheiro, Natalie conseguiu comprar um apartamento no Horto, saindo da comunidade onde nasceu para viver na zona Sul do Rio de Janeiro com a mãe, Haidê Batista (Rosi Campos), e o irmão, Douglas Batista (Ricardo Tozzi).

Três anos após o fim do programa, enfrentando a perda de capital de visibilidade, Natalie buscava avidamente se manter na mídia. O momento de ostracismo e seus gastos com roupas e produtos estéticos fazem com que sua mãe, faxineira, sustente os filhos adultos. Haidê está constantemente desapontada com os dois, já que não seguem seu exemplo de trabalho esforçado.

9 Agradeço pelos comentários de Samuel Paiva, Marcio Serelle e Vera França, que contribuíram para o aprimoramento do trabalho. 
Natalie é a celebridade de Daniel Boorstin (1992, p. 57), "conhecida por ser conhecida", personagem fabricada para aparecer na mídia. Segundo Boorstin, a celebridade é um produto moldado para suprir as demandas da mídia por mais personagens, que são intrinsecamente descartáveis. Fruto de uma maquinação industrial, o desaparecimento da celebridade não é dramático, pois está previsto em sua própria formação. Ao longo da novela, Natalie luta contra o destino inexorável da celebridade (o desaparecimento e, consequentemente, o anonimato) desenvolvendo, para isso, diversas estratégias.

No primeiro capítulo da trama, ela surge em um salão de beleza, realizando tratamentos estéticos e capilares. Quando está indo embora, a secretária do estabelecimento cobra o pagamento. Natalie diz que nunca paga por seus tratamentos. "Tenho permuta e sempre cito a clínica em minhas entrevistas". A secretária insiste na cobrança: "Imagine quantas finalistas de reality show já surgiram depois de você, imagine se fizermos permuta com todas elas...".

Na cena seguinte, Natalie está em um bar com seu assessor de imprensa Roni Fragonard (Leonardo Miggiorin) e revela que a conta do salão de beleza tinha sido paga com um cheque sem fundos. Natalie pede que ele consiga uma "presença VIP"11 em um evento onde André Gurgel (Lázaro Ramos), um designer bem-sucedido, seria premiado. A ideia de Natalie surgiu enquanto ela lia a notícia da premiação em revistas de fofoca no salão de beleza, anunciando para todos que André era o "bofe perfeito". A oportunidade de trabalhar no evento era duplamente auspiciosa: conseguir algum dinheiro e ainda ter a chance de conhecer André. Roni lembra que Natalie precisa "cair na real", pois não estava mais em alta e que nem um convite para o evento ela conseguiria ganhar.

Na sequência, Natalie aparece na academia, conversando com a modelo Daniela Sarahyba, que iria ao evento para entregar o prêmio para André. Natalie pergunta se a modelo tinha companhia, e Daniela diz que não. Natalie consegue que Daniela a leve como acompanhante. Ao descer do carro, Natalie coloca o pé na frente de Daniela, que tropeça. Como ela não se machuca, Natalie faz outra 
armação, colocando tranquilizante na taça de champanhe de Daniela. Daniela dorme, cabendo a Natalie entregar o prêmio a André.

A situação em que Natalie se envolve no primeiro capítulo da novela estrutura os conflitos vividos pela personagem ao longo da trama, causados por dois esforços, muitas vezes, mal sucedidos. O primeiro consiste no desejo de aparecer na mídia através de estratégias antiéticas, como o caso do tranquilizante. O segundo é encontrar um bom marido, empenhando-se para estar em lugares que favoreçam seus encontros, como na entrega do prêmio a André.

Ainda no início da novela, aproximadamente no $30^{\circ}$ capítulo, Natalie desiste do relacionamento com André e se interessa por Horácio Cortez (Herson Capri), banqueiro rico e um dos vilões da trama. Depois de descobrir que ele é casado, Natalie quer que ele se separe da mulher, Clarice (Ana Beatriz Nogueira), pois deseja ser reconhecida como esposa de Horácio, afirmando a necessidade de ter "estabilidade financeira". Natalie elabora um plano para que Horácio se divorcie, gravando um vídeo íntimo em que ele afirma "nunca ter amado" a esposa. Depois de receber as imagens, Clarice decide pedir a separação. Horácio, vendo seu patrimônio ameaçado, contrata um matador para sabotar os freios do carro da mulher, que morre em um acidente. Natalie não sabe do envolvimento de Horácio no crime, mas comemora o ocorrido, pois, enfim, alcançou seu objetivo, casando-se com ele, no capítulo 118. Natalie passa a viver em sua mansão, lidando com algumas situações conflituosas, como os embates com os enteados e a desaprovação de sua mãe.

No desfecho da trama, envolvido em um caso de corrupção, Horácio acaba sendo preso. Natalie escapa de qualquer acusação ou da má reputação de seu marido. Ela ganha um cachê de $\mathrm{R} \$ 1$ milhão posando nua como "musa da justiça, pelo fim da impunidade" e, em seguida, torna-se deputada federal, prometendo "fazer uma lipoaspiração na corrupção".

Natalie, durante toda a novela, esteve obcecada pelo desejo de ter sucesso. A dona de casa Eunice Alencar Machado (Débora Evelyn), vizinha de Natalie, por 
exemplo, também era uma personagem ambiciosa. Ela queria se aproximar da "elite carioca", buscando laços de amizade que a fariam se sentir enturmada no clube da elite. No lançamento da revista masculina Fogo Alto, Natalie convida Eunice para o evento, que aceita o convite imaginando que Natalie, sendo uma pessoa conhecida, poderia a introduzir às figuras da elite. Sem saber que se tratava de um ensaio sensual, Eunice se escandaliza. O diálogo entre as duas revela distintas estratégias de ascensão social: Eunice se refere a Natalie como "piromaníaca indecente"; ela se refere a Eunice como "perua histérica e moralista". Natalie tem razão, pois a censura ao uso do corpo se relaciona a valores morais, a base negativa da pirâmide erótica de Gayle Rubin.

Para Eunice, a exposição do corpo é coisa de "vagabunda"; para Natalie, a imitação dos modos da elite é "cafonice". No entanto, estar em evidência, ter muito dinheiro, projeção pública e status são os objetivos de ambas. Os planos para alcançá-los são distintos - Natalie, oriunda de classes baixas, usa o corpo; Eunice, de classe média, a destreza com o habitus das classes altas.

Constantemente, Natalie sente-se ameaçada por um grande temor: voltar a ser pobre e a viver na favela. Sua expectativa de futuro é, portanto, marcada pela incerteza de não ser capaz de manter o padrão de vida alcançado com a fama. Os métodos que Natalie adota para evitar a decadência financeira são racionais, conjugados com a oferta, também calculada, de sexo. Ao longo da trama, além de transar com André e Horácio, ela vai para a cama algumas vezes com Wagner (Eduardo Galvão), advogado de Horácio. Assim, o sexo, para Natalie, não tem ligação com prazer. Ela está sempre em busca de alguma troca de interesse com seus parceiros.

\section{A personagem Suelen}

Em Avenida Brasil, escrita por José Emanuel Carneiro e exibida entre 26 de março de 2012 a 19 de outubro de 2012, em 180 capítulos, Suelen era funcionária da loja A Elegância Diógenes Modas Femininas, no Divino, bairro do subúrbio do Rio de Janeiro. Suelen, ao contrário de Natalie, não 
tinha família e vivia sozinha em um quarto alugado; sua vida pregressa não foi apresentada no início da trama. Seu sonho era melhorar de vida, conquistando um jogador de futebol de sucesso. Por isso, frequentava os treinos do time do bairro em busca de um bom partido.

Na primeira aparição na novela, Suelen está chegando, mais uma vez, atrasada para trabalhar. O patrão, Diógenes (Otávio Augusto), a repreende, mas ela entrega a ele um atestado médico. Ao iniciar sua jornada de trabalho, Suelen, atrás do balcão, mexe distraída em seu celular, quando uma cliente pede uma informação sobre uma calça legging da vitrine. Sem demonstrar nenhum interesse em atendê-la, Suelen, olhando para o corpo da cliente, afirma que a calça iria deixá-la como um "elefante de circo". A mulher sai da loja chateada, e uma colega de trabalho, percebendo o que ocorreu, diz que Suelen poderia perder o emprego a qualquer momento. Ela responde que não liga, pois sua vida iria mudar, depois que vencesse o concurso Miss Chapinha. Suelen, ao contrário de Natalie, não surge constrangida pelas dificuldades que enfrenta. Mesmo depois de chegar atrasada e ser repreendida pelo patrão, Suelen não se sente incomodada. Natalie busca um trabalho, pois está "precisada"; Suelen acredita que a vida pode mudar em breve pela vitória no concurso de beleza.

As cenas seguintes mostram os bastidores do concurso Garota Chapinha, no Divino Esporte Clube, local de sociabilidade dos personagens da novela. Suelen descobre que tem uma forte concorrente, Tessália (Débora Nascimento), e decide quebrar um dos saltos de seu sapato. Tessália cai na passarela durante o desfile. No camarim, Olenka (Fabiula Nascimento) flagra um vidro de cola na bolsa de Suelen, que confessa a sabotagem. Diógenes a desclassifica, e Tessália vence o concurso.

No dia posterior ao concurso, Suelen chega atrasada novamente ao trabalho. Diógenes decide despedi-la pelos constantes atrasos, lembrando também seu desapontamento com ela no concurso. Suelen pergunta se Diógenes poderia fazer o acerto naquele momento, no escritório da loja. Enquanto ele faz as contas, Suelen tira a sua roupa, seduz o patrão, e eles transam. Diógenes volta atrás de sua decisão. Na manhã seguinte, Suelen mais uma vez se atrasa. 0 
patrão, na porta a aguardando, avisa que ela, uma "vadiazinha", estava demitida. Dizendo que tem carteira assinada, Suelen pede ao patrão para fazer o acerto com ela. Novamente no escritório, Suelen revela que gravou um vídeo da transa do dia anterior e explica que "assédio sexual, o pessoal da justiça adora e, na internet, então, com a nome da loja no fundo, olha que amor, vai bombar".

Algumas semelhanças entre as primeiras aparições de Natalie e Suelen podem ser notadas: a situação de ritual público, a sabotagem contra outras concorrentes relacionada ao "cair do salto alto" e a aspiração de ocupar um lugar de destaque na cena visível. Natalie e Suelen planejaram racionalmente um golpe e são mulheres traiçoeiras, pois se aproximaram das vítimas para, em seguida, enganá-las. A periguete não engana somente homens, ela também trai a confiança de mulheres. Natalie alcançou seu objetivo, pois conseguiu entregar o prêmio a André. Suelen, ao contrário, não venceu o concurso e ainda foi descoberta pela sabotagem.

Suelen, diferentemente de Natalie, não se envolve com homens ricos e famosos. Ela nunca foi famosa, não alcançou quase nada na vida, e sua profissão, vendedora, permite uma ambição mais modesta. Os problemas de Suelen e a utilidade do sexo se inscrevem na vida cotidiana: reverter a sua demissão por faltas e atrasos no trabalho. A oferta também é calculada, mas não há uma grande aspiração no sexo com Diógenes. Suelen é também mais liberada que Natalie - que só aceita transar com Horácio depois que ele afirma ter se separado, por exemplo.

Ao longo da novela, a trajetória de Suelen se constitui pela constante busca de um parceiro nos treinos de futebol do Divino Esporte Clube. Ela se envolve com Iran (Bruno Gissoni), planejando dar o "golpe do baú" no filho de Monalisa (Heloísa Perissé), mulher bem-sucedida do bairro. Ela se relaciona ainda com Leandro (Thiago Martins), jovem do interior de Goiás, recém-chegado ao Divino Esporte Clube como futura promessa do futebol, e se casa com Roni (Daniel Rocha), filho de Diógenes. Suelen transa também com Darkson (José Loreto), Adauto (Juliano Cazarré) e Lúcio (Emiliano D’Avila). 
No 190 capítulo, Suelen é despejada do quarto que alugava no bairro e passa a viver na casa de Diógenes que, naquele momento, também acolhia Leandro. Despertando ciúmes de Roni, que demonstrava atração por Leandro, Suelen é incorporada ao cotidiano da família. A partir do $70^{\circ}$ capítulo seu passado é revelado: Suelen nasceu na Bolívia e veio ao Brasil, ainda adolescente, para se prostituir. Ainda em débito com Ramon (William Vita), cafetão que a trouxe para o país, Suelen é sequestrada por ele. Roni descobre o cativeiro e tenta resgatála. Espancado pelos criminosos, ele ainda leva um tiro, mas consegue salvar Suelen. Sem visto de permanência no Brasil, ela é presa para ser deportada. Ao visitá-la na delegacia, Leandro propõe que eles se casem para que ela possa ficar no Brasil. Suelen não aceita, alegando que "eu não sou moça para casar, muito menos contigo, pobre lascado que nem eu. Aliás, pobreza na Bolívia é igual". Em seguida, Roni decide também pedir Suelen em casamento. Ele explica que, caso ela aceitasse, ele ganharia um apartamento do pai. Além disso, os vizinhos não diriam mais que ele era gay. Suelen aceita, e os dois se casam, alegrando a mãe de Roni, Dolores Neiva (Paula Burlamaqui), uma ex-atriz pornô que havia se tornado evangélica e sofria com a homossexualidade do filho.

A partir daquele momento, Suelen passa a seduzir Roni e consegue transar com ele algumas vezes. Ela se converte em uma esposa exemplar e passa a trabalhar com dedicação na loja A Elegância. No entanto, ao longo do tempo, Leandro demonstra que tem ciúmes de Suelen e, Roni, por sua vez, falta de Leandro. O triângulo amoroso é constituído por muitas sugestões e insinuações até que, depois de algum tempo, Leandro decide se mudar da casa de Diógenes para o apartamento de Roni e Suelen. Diógenes não concorda com a mudança de Leandro e pergunta aos três: "Que história é esta, que laranja é esta de vocês que tem três metades? A casa do Roni é pequena, vocês vão dormir como? Um em cima do outro?" No desfecho da história, Suelen engravida e os três, Roni, Leandro e Suelen, formam uma nova família.

Procurando informações a respeito de Suelen, encontrei muitas páginas e vídeos de homenagem ao seu relacionamento com Roni, que traziam frases como "o casal perfeito", "o 
casal mais fofo", "fora Leandro"12. Nas homenagens, o casamento de fachada, a ambição de Suelen e a homossexualidade de Roni não são tematizadas. Existe, nas homenagens, uma história romântica, que superou barreiras. Roni é o antigo herói moderno, que salvou a vida de Suelen ${ }^{13}$. A sua própria vida masculina também foi salva, pois, ao se tornar heterossexual, ele se afastou da base da pirâmide negativa do comportamento sexual desviante.

\section{Considerações finais}

A mulher fatal pode ser definida como alguém que alcança seus objetivos através da sedução, do uso de truques do corpo feminino. Julie Grossman (2010) indica que a popularização da imagem da mulher fatal no século XX, através do cinema, demonstra a complexidade dos novos lugares sociais femininos. A mulher fatal indica que as fontes do selffeminino moderno se orientam pela ambição, trazendo novas perspectivas para a compreensão do sentido da ação das mulheres.

Quando Suelen aceita se casar com Roni - e não com Leandro - a motivação é a celebração de um bom negócio. Se fosse por paixão ou pelo simples desejo de ficar no Brasil, Suelen poderia ter aceitado se casar com Leandro. Assim como Natalie, o casamento para Suelen significa uma chance de ascender socialmente e deve ser muito bem calculado. Ao comentar que a pobreza na Bolívia seria muito semelhante à pobreza no Brasil, ela quer dizer que apenas uma vida melhor a faria ficar. Sua vinda para o Brasil como prostituta deve ter sido cercada pelas expectativas de melhorar de vida. O casamento de fachada com Roni teria como recompensa um apartamento para os dois viverem e a possibilidade de um futuro promissor, pois Roni se tornaria um jogador de futebol "macho".

Para Suelen, uma vida bem-sucedida significa ter dinheiro, objetivo similar ao de Natalie. Muitas vezes, as atitudes estratégicas das duas se parecem: gravam cenas de sexo no celular para chantagear os parceiros, provocam incômodo nas mulheres do bairro onde vivem e realizam fotografias nuas. Nos dois casos, a 
presença da polícia também é semelhante: ambas se envolvem em crimes - elas não são propriamente criminosas, mas cometem delitos e estão próximas de situações que as levam à aproximação com a polícia. Os crimes em que Natalie se envolve relacionam ao universo das classes altas, crimes de colarinho branco: lobby, desvio de dinheiro, falsificação de documentos. Já Suelen se relaciona a crimes das classes mais pobres, sendo vítima do tráfico de mulheres e de exploração sexual.

Suelen se aproxima da condição de celebridade quase no final da trama, quando Leandro é contratado pelo Flamengo. Apesar de não ser uma ex-participante de reality show, Suelen demonstra que sabe como agir como celebridade, produzindo o visual de Leandro para se tornar um grande jogador e se desapontando por sua fotografia não ter sido publicada em uma revista de fofoca.

Ao contrário de Natalie, que conquista a eleição de deputada, retornando gloriosa à vida público-midiática, Suelen tem um desfecho mais modesto, relacionado apenas ao âmbito privado: a formação de uma família. Apesar de pouco convencional, sua família indica a contenção do final da história (parece que Suelen, enfim, estará satisfeita transando com dois maridos e não mais com todo o bairro). Comparada a Natalie, o sonho de Suelen era mais modesto, ter dinheiro e uma vida melhor, o que ela, por fim, conseguiu. "Ser alguém na vida", para ela, era ter uma vida mais estável, fora das ruas, tendo mais prazer no cotidiano. Os dois finais são felizes dentro dos horizontes de expectativas de cada personagem.

A análise da performance de sexo articulada com outras estruturas sociais (RUBIN, 2011; GILL, 2011) indica que, nos dois casos, a periguete dá visibilidade a uma problemática de classe na mídia. Como aponta Jesse Souza (2006), a invisibilidade da desigualdade brasileira se constitui através da incorporação de valores modernos no país. A crença na cultura do mérito encobre o fato de que, no Brasil, as condições para alcançar, por si mesmo, a ascensão social são ilusórias. A desigualdade se torna invisível, pois se acredita que ela é legítima dentro do esforço de modernização brasileira. A periguete traz a perturbação da ordem invisível da desigualdade, manifestando visualmente o descompasso que existe, em um país desigual, entre o discurso do mérito e a falta de acesso às condições básicas da existência. 


\section{Referências}

ALMEIDA, H. B. "Consumidoras e heroínas: gênero na telenovela". Revista Estudos Feministas. Florianópolis, v. 15, n. 1, abril 2007.

BERALDO, B. "Periguetes e vadias: por saias e causas justas". In: IX POSCOM - Seminário dos Alunos de Pós-Graduação em Comunicação Social da PUC-Rio. Rio de Janeiro: 07-09 de novembro de 2012.

BOORSTIN, D. The image: a guide to pseudo-events in America. New York, Vintage Books, 1992.

ESCOSTEGUY, A. C. "Histórias de vida exemplares: heroísmo e melodrama em ação". Matrizes, São Paulo, n. 2, p. 143-159, jul.-dez. 2013.

GROSSMAN, J. "Reading women as wicked in American film noir". In: HANSON, H.; O'RAWE, C. The femme fatale: images, histories, contexts. New York: Palgrave MacMillan, 2010.

GILL, R. "Sexism reloaded, or, it's time to get angry again". Feminist Media Studies, vol.11, n. 1, p.61-71, 2011.

HANSON, H.; O'RAWE, C. The femme fatale: images, histories, contexts. New York: Palgrave MacMillan, 2010.

LANA, L. "A visibilidade midiática na celebrização feminina: Catarina, uma virgem à leilão". Comunicacão, Mídia e Consumo, v. 10, p. 13-30, 2013.

LANA, L.; CORREA, L.; ROSA, M. "A cartilha da mulher adequada: ser piriguete e ser feminina no Esquadrão da Moda". Contracampo, Niterói, v. 24, p. 120-139, 2012. 
MATTOS, P. "A mulher moderna numa sociedade desigual". In: SOUZA, J. (Org.). A invisibilidade da desigualdade brasileira. Belo Horizonte: Editora UFMG, 2006. p. 153-196.

MESSA, M. R. "As mulheres só querem ser salvas: produção, texto e recepção de Sex and the city". In: EscosteguY, A. C. (org.). Comunicação e gênero: a aventura da pesquisa. Porto Alegre: EDIPUCRS, 2008. p. 131-168.

RONSINI, V.; DEPEXE, S.; SCHERER, F.; SCHNORR, J.; GELAIN, G. "Aspirações femininas: modelos da televisão e da vida". In: XXII Encontro Anual da Compós, 2013, Salvador, 2013. p. 1-16.

RUBIN, G. "Thinking sex". In: RUBIN, G. Deviations: a Gayle Rubin reader. Durham \& London: Duke University Press, 2011, p. 137-181.

SOUZA, J. "A gramática social da desigualdade brasileira". In: SOUZA, J. (org.). A invisibilidade da desigualdade brasileira. Belo Horizonte: Editora UFMG, 2006. p. 23-54. 